\title{
Economic Analysis of Krishi Bhagya Scheme on Cost and Return of Stakeholders
}

\author{
S. Raveesha ${ }^{1 *}$, Basavalingaiah ${ }^{2}$, L.B. Ashok $^{3}$ and K.L. Vasudev ${ }^{4}$ \\ ${ }^{1}$ Department of Agricultural-Economics, College of Horticulture, Hiriyur, India \\ ${ }^{2}$ Department of NRM, College of Horticulture, Hiriyur, India \\ ${ }^{3}$ Department of Soil Science and Agricultural Chemistry, Dept. of NRM, College of \\ Horticulture, Hiriyur, India \\ ${ }^{4}$ Department of Farm Forestry, Dept. of NRM, College of Horticulture, Hiriyur, India \\ *Corresponding author
}

\begin{tabular}{|c|c|}
\hline \multicolumn{2}{|r|}{ A B S T R A C T } \\
\hline & \multirow{7}{*}{$\begin{array}{l}\text { Rural development as an integrated concept of growth and poverty elimination has been of } \\
\text { paramount concern in all the consequent Government Schemes. The major challenge for } \\
\text { our Governments is to offer solution that enables rain fed farming towards sustainable } \\
\text { agriculture. "Krishi Bhagya" is the Government's flagship programme is a step towards to } \\
\text { achive sustainability among rainfed farmers of the state. Government is supporting farmers } \\
\text { to make a farm pond with polythene lining (to prevent percolation), install pump and } \\
\text { sprinkler irrigation system (for efficient water utilization). This intervention helps farmers } \\
\text { to harvest surplus rainwater and use it as lifesaving irrigation to sustain the production and } \\
\text { thereby it is possible to enhance the yield by } 30 \text { per cent. In order to evaluate the } \\
\text { performance of the scheme the study has made use the primary data. Primary data was } \\
\text { collected from } 15 \text { beneficiaries and } 10 \text { Non-beneficiaries by using pre-tested structured } \\
\text { schedules. The required data was collected from different sources, beneficiary households } \\
\text { and villages. The data clearly indicates that the cropping pattern has been changed along } \\
\text { with net income and no of irrigations per acre in both the districts. In Davanagere District } \\
\text { after the implementation of KrishiBhagya Paddy and maize crops were replaced by } \\
\text { Tomato and chilli. Where as in Chithradurga maize and groundnut were replaced by onion } \\
\text { and marigold. }\end{array}$} \\
\hline & \\
\hline Econc & \\
\hline $\begin{array}{l}\text { KrishiBhagya, } \\
\text { Crops, Cost and } \\
\text { Return }\end{array}$ & \\
\hline Article Info & \\
\hline & \\
\hline & \\
\hline
\end{tabular}

\section{Introduction}

Rural development as an integrated concept of growth and poverty elimination has been of paramount concern in all the consequent Government Schemes. A majority of people in India live in villages and about 50 per cent of the villages have very poor socio-economic conditions. Since the dawn of independence, concerted efforts have been made to uplift the living standards of rural masses. The major challenge for our Governments is to offer solution that enables rain fed farming towards sustainable agriculture. Though dry spells at crucial times of crop cycles, nevertheless cumulative rainfall tends to hovers, around the average rainfall by about a margin of 20 per cent. This should suffice for a fair crop. 
Challenge is to harvest the run-off rain water of field and use it for crops when dry spells occur.

"Krishi Bhagya" is the Government's flagship programme is a step towards to achive sustainability among rainfed farmers of the state. Government is supporting farmers to make a farm pond with polythene lining (to prevent percolation), install pump and sprinkler irrigation system (for efficient water utilization). This intervention helps farmers to harvest surplus rainwater and use it as lifesaving irrigation to sustain the production and thereby it is possible to enhance the yield by 30 per cent. This intervention can potentially help farmers to stand on their own feet.

\section{Materials and Methods}

In order to evaluate the performance of the scheme the study has made use the primary data. Primary data was collected from 15 beneficiaries and 10 Non-beneficiaries by using pre-tested structured schedules. The required data was collected from different sources, beneficiary households and villages.

The data collected includes details about the major objectives of the farm and its activities. Data was gathered about the area of the farm and land use patterns, infrastructure and facilities on the farm, number of animals, etc. Information on the cropping pattern, sources of irrigation, details about the financial and physical targets achieved in respect of KrishiBhagya Schemes, assets created and other aspects of the schemes was collected. Along with that information about the constraints faced in the implementation of the schemes and suggestion for effective implementation of the schemes was sought.

Two districts, namely, Chitradurga and Davanagere were chosen for the study. One taluk from each District was selected randomly from where the scheme was implemented. A list of villages and beneficiaries were obtained from the Assistant Director of Agriculture, Department of Agriculture. Located at the respective district headquarters. Finally, 15 beneficiary and 10 Non- beneficiary households were selected from 5 contiguous villages. Beneficiaries were interviewed to elicit their views on the programme and its impact.

A random sampling design will be followed for the collection of data in selected taluks. The villages under the scheme formed the first and second stage unit of sampling while the ultimate unit of sampling was household farmer. The villages were selected in such a manner so as to cover the beneficiaries and non-beneficiaries identified for the study.

Although a common schedule was canvassed for data collection for the taluks, some degree of freedom was given to the field assistants and Research Associate for including or excluding certain items in the schedule depending upon the conditions specific to region. 25 farmers were interviewed.

Simple averages, ratios, percentages and required Statistical and Economical tools were employed to analyze the data to draw meaningful inferences.

\section{Results and Discussion}

The information in the table 1 depicts the cropping pattern, net income and no of irrigations per acre before and after the implementation of KrishiBhagya Scheme. The data clearly indicates that the cropping pattern has been changed along with net income and no of irrigations per acre in both the districts. In Davanagere District after the implementation of krishiBhagya Paddy and maize crops were replaced by Tomato and 
chilli. Where as in chithradurga maize and groundnut were replaced by onion and marigold. In Davangere the average net income per acre has been increased from Rs.14000, 11750 and 35000 to 21200, 15660 , 43000 and 40000 . The number of irrigations was also increased from 16,9 and 13 to 18 , 10,15 and 12 in case of paddy, maize, tomato and chilly respectively. In case of Chitadurga the average net income per acre was
Rs.10000, 13000 and 35000 from the crops Maize, groundnut and onion and the number of irrigation per acre was 6,8 and 10 respectively before the implementation of the KrishiBhagya. After the implementation of KrishiBhagyathr net income per acre had been increased to Rs.15000, 47500 and 40000 from maize, onion and marigold and the number of irrigations per acre was 8,10 and 12 respectively.
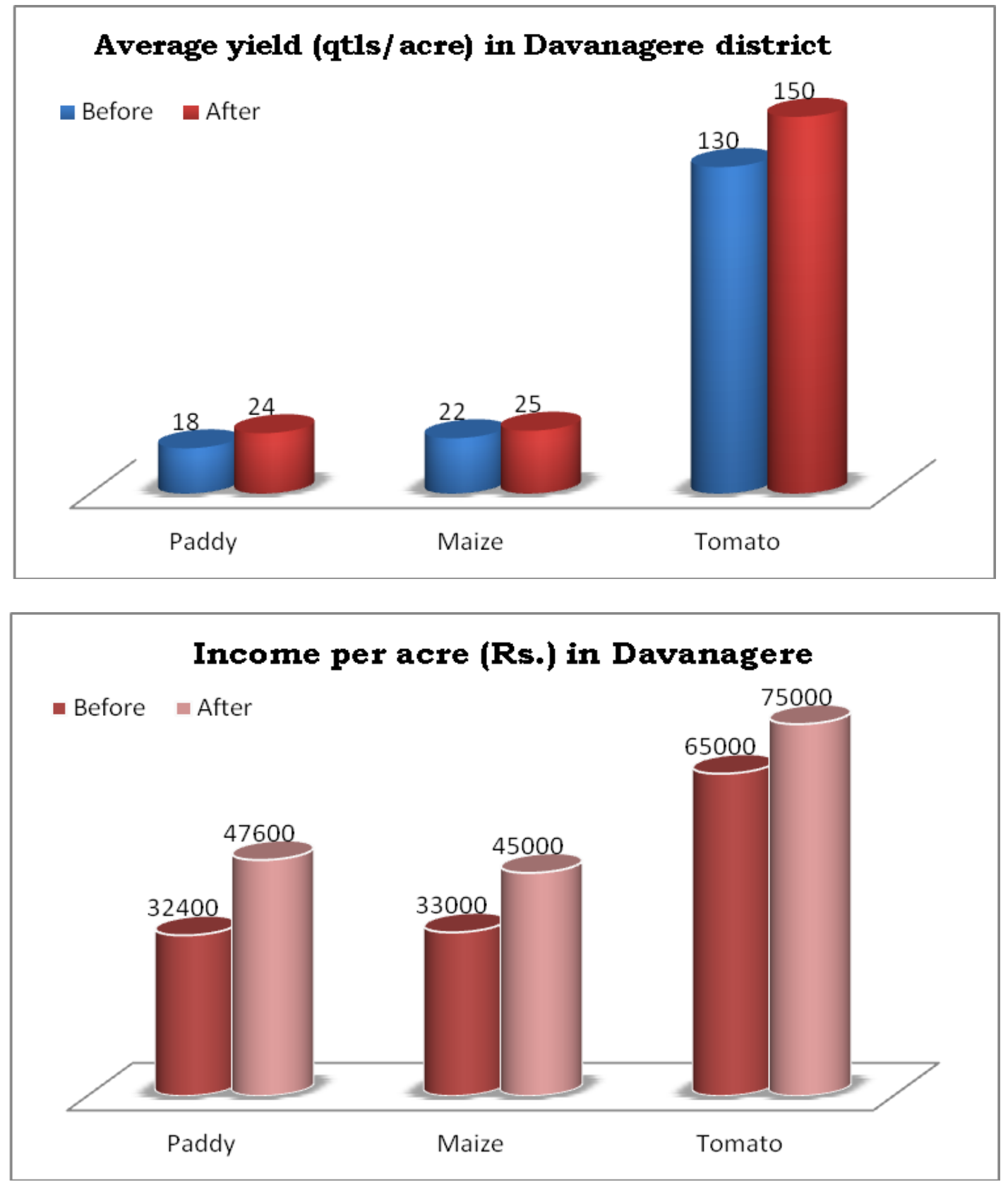
Table.1 Cost of cultivation (Rs/ac) and net income (Rs/ac) of the respondent farmers

\begin{tabular}{|c|c|c|c|c|c|c|c|c|c|c|c|c|c|}
\hline \multicolumn{14}{|c|}{ DAVANAGERE DISTRICT } \\
\hline $\begin{array}{l}\text { Crops } \\
\text { cultivated }\end{array}$ & $\begin{array}{l}\text { Area } \\
\text { (ac) }\end{array}$ & $\begin{array}{l}\text { Avg. } \\
\text { yield } \\
\text { qtl/ac }\end{array}$ & $\begin{array}{l}\text { Cost of } \\
\text { Cultiva } \\
\text { tion } \\
\text { (Rs) }\end{array}$ & $\begin{array}{l}\text { Income } \\
\text { Rs/ac }\end{array}$ & $\begin{array}{l}\text { Net } \\
\text { income } \\
\text { Rs/ ac }\end{array}$ & $\begin{array}{l}\text { No. of } \\
\text { irrigatio } \\
\text { ns /crop }\end{array}$ & $\begin{array}{l}\text { Crops } \\
\text { cultivate } \\
\text { d }\end{array}$ & $\begin{array}{l}\text { Area } \\
\text { (ac) }\end{array}$ & $\begin{array}{l}\text { Avg. } \\
\text { yield } \\
\text { qtl/ac }\end{array}$ & $\begin{array}{l}\text { Cost of } \\
\text { Cultivati } \\
\text { on (Rs) }\end{array}$ & $\begin{array}{l}\text { Income } \\
\text { Rs/ac }\end{array}$ & $\begin{array}{l}\text { Net } \\
\text { income } \\
\text { Rs/ ac }\end{array}$ & $\begin{array}{l}\text { No. of } \\
\text { irrigatio } \\
\text { ns /crop }\end{array}$ \\
\hline Paddy & 7 & 20 & 22000 & 36000 & 14000 & 16 & Paddy & 6 & 24 & 24000 & 45200 & 21200 & 18 \\
\hline Maize & 4 & 20 & 18250 & 30000 & 11750 & 9 & Maize & 2 & 23 & 18840 & 34500 & 15660 & 10 \\
\hline \multirow[t]{2}{*}{ Tomato } & 1 & 130 & 30000 & 65000 & 35000 & 13 & Tomato & 2 & 150 & 32000 & 75000 & 43000 & 15 \\
\hline & & & & & & & Chilli & 2 & 115 & 20000 & 60000 & 40000 & 12 \\
\hline \multicolumn{14}{|c|}{ CHITHRADURGA DISTRICT } \\
\hline \multicolumn{7}{|c|}{ Before } & \multicolumn{7}{|c|}{ After } \\
\hline $\begin{array}{l}\text { Crops } \\
\text { cultivated }\end{array}$ & $\begin{array}{l}\text { Area } \\
\text { (ac) }\end{array}$ & $\begin{array}{l}\text { Avg. } \\
\text { yield } \\
\text { qtl/ac }\end{array}$ & $\begin{array}{l}\text { Cost of } \\
\text { Cultiva } \\
\text { tion } \\
\text { (Rs) }\end{array}$ & $\begin{array}{l}\text { Income } \\
\text { Rs /ac }\end{array}$ & $\begin{array}{l}\text { Net } \\
\text { income } \\
\text { Rs/ ac }\end{array}$ & $\begin{array}{l}\text { No. of } \\
\text { irrigatio } \\
\text { ns /crop }\end{array}$ & $\begin{array}{l}\text { Crops } \\
\text { cultivati } \\
\text { on }(\mathbf{R s})\end{array}$ & $\begin{array}{l}\text { Area } \\
(\mathbf{a c})\end{array}$ & $\begin{array}{l}\text { Avg. } \\
\text { yield } \\
\text { qtl/ac }\end{array}$ & $\begin{array}{l}\text { Cost of } \\
\text { Cultivati } \\
\text { on (Rs) }\end{array}$ & $\begin{array}{l}\text { Income } \\
\text { Rs /ac }\end{array}$ & $\begin{array}{l}\text { Net } \\
\text { income } \\
\text { Rs/ ac }\end{array}$ & $\begin{array}{l}\text { No. of } \\
\text { irrigatio } \\
\text { ns /crop }\end{array}$ \\
\hline Maize & 2 & 18 & 17000 & 27000 & 10000 & 6 & Maize & 1 & 22 & 18000 & 33000 & 15000 & 8 \\
\hline Groundnut & 3 & 8 & 20000 & 33000 & 13000 & 8 & Onion & 5 & 110 & 46000 & 93500 & 47500 & 10 \\
\hline onion & 2 & 80 & 45000 & 80000 & 35000 & 10 & $\begin{array}{l}\text { Marygol } \\
\text { d }\end{array}$ & 1 & 80 & 40000 & 80000 & 40000 & 12 \\
\hline
\end{tabular}


KrishiBhagya Scheme has positive impact on annual income of the beneficiaries.

So, it is suggested that all farming families may utilize facilities of KrishiBhagya Scheme to improve their socio-economic life and

Also the government may take up measures to cover all the farming families.

The cost of cultivation and gross income of the beneficiary farmers was higher in both

The districts compared to non-beneficiary farmers.

It is because of positive impacts of KrishiBhagya Scheme activities like Krushi Honda, KshetraBadhu,

Polythene sheet, Cropping Pattern, PashuBhagya and so on.

The government may implement the scheme activities to all rural farming families wherever it is feasible to increase the income of the Farmers.

\section{References}

Acharya, S S (2001). Domestic Agricultural Marketing Policies, Incentives and Integration. In S S Acharya and D P Chaudhri (ed.) Indian Agricultural Policy at the Cross Roads, Jaipur: Rawat.

Adhikari, A. and K. Bhatia (2010), "Can we Bank on Banks?" Economic and Political Weekly, January 2.

Agricultural Finance Corporation Limited. 2014. Report on Impact evaluation of National Food Security Mission. New Delhi.
Aiyar, Yamini and Salimah Samji (2006), "Improving the Effectiveness of National Rural Employment Guarantee Act", Economic and Political Weekly, January 28, pp. 320-326.

Basu Arnab K. (2011), "Impact of rural employment guarantee schemes on seasonal labor markets: Optimum compensation and workers' welfare", discussion Paper No. 5701, $Z E F$, University of Bonn Germany and IZA, May 2011

Bhalla Sheila, Anup K. Karan and T. Shobha (2004). "Rural Casual Labourers, Wages and Poverty", working paper 14. New Delhi: Chronic Poverty Research Centre and Indian Institute of Public Administration.

Deshpande, R.S. (1988). Medium Term Perspective for Karnataka Agriculture. In Karnataka: Perspective Plan 2001, Report of the Expert Group (L C Jain Committee), Vol. II. Bangalore: Government of Karnataka.

Deshpande, R.S. and K.V. Raju (2001). Rural Policy for Growth and Poverty Reduction. Bangalore: Agricultural Development and Rural Transformation Unit, Institute for Social and Economic Change.

Dev, S.M and Sharma. A. N. 2010. Food Security in India: Performance, Challenges and Policies. Oxfam India working papers series. OIWPS- VII.

Gopalappa, D.V. (2004). "Rural Non-Farm Employment in Karnataka". Bangalore: ADRT Unit, Institute for Social and Economic Change (ISEC Report).

Lakshamanan and Geethadevi (2004): Growth of mulberry silk production in India, Productivity, pp. $300-306$.

Nabard consultancy services. 2011. Concurrent evaluation report of NFSM in Rajasthan.

\section{How to cite this article:}

Raveesha, S., Basavalingaiah, L.B. Ashok and Vasudev, K.L. 2019. Economic Analysis of Krishi Bhagya Scheme on Cost and Return of Stakeholders. Int.J.Curr.Microbiol.App.Sci. 8(08): 14251429. doi: https://doi.org/10.20546/ijcmas.2019.808.166 